\title{
FUNGSI TUTUR KALIMAT TANYA BAHASA INDONESIA
}

\author{
Lindawati \\ Fakultas Ilmu Budaya Universitas Andalas Padang \\ e-mail: lindawatisaun@yahoo.co.id
}

\begin{abstract}
Abstrak
Penelitian ini mengkaji masalah kalimat tanya bahasa Indonesia dengan berfokus pada masalah fungsi tutur. Data yang dipakai dalam penelitian ini adalah kalimat tanya bahasa Indonesia yang sekarang ini digunakan dalam komunikasi antaretnis. Penelitian ini menggunakan pendekatan pragmatik yang memandang bahwa di saat seorang menuturkan suatu kalimat secara serta merta orang itu menindakkan sesuatu yang kemudian disebut dengan tindak tutur. Kalimat tanya yang pada dasarnya dituturkan untuk menanyakan tentang sesuatu juga digunakan untuk menyatakan berbagai tindak tutur. Dari penelitian yang dilakukan, ditemukan empat jenis tindak tutur yang dapat dinyatakan dengan kalimat tanya, yaitu tindak representatif, direktif, komisif, dan ekspresif. Kalimat tanya adakalanya digunakan dalam rangka bertutur tidak langsung untuk menjaga kesopanan (mengurangi kekerasan) atau sebaliknya menyatakan dengan tegas, kasar dan bahkan ada yang dianggap kurang ajar.
\end{abstract}

Kata kunci: fungsi, kalimat, tanya, variasi, konteks

\section{SPEECH FUNCTIONS OF INTERROGATIVE SENTENCES IN INDONESIAN}

\begin{abstract}
This study examines interrogative sentences in Indonesian by focusing on speech functions. The data were interrogative sentences in Indonesian nowadays used in communication among ethnic groups. It employed the pragmatic approach stating that when one is saying a sentence at the same time s/he is performing an action called a speech act. An interrogative sentence, which is basically used to ask a question about something, can also be used to express a variety of speech acts. The findings show that there are four speech acts expressed by interrogative sentences, namely representative, directive, comissive, and expressive acts. Interrogative sentences are sometimes used to express indirect speech acts to maintain politeness (to soften the tone) or to express something firmly, rudely, and even impolitely.
\end{abstract}

Keywords: functions, interrogative sentences, variations, contexts

\section{PENDAHULUAN}

Seseorang dikatakan menguasai suatu bahasa apabila dia dapat berkomunikasi dalam bahasa itu untuk berbagai keperluan hidupnya sehari hari, baik itu untuk komunikasi dalam rumah tangga, ditempat bekerja atau ditempat umum yang lainnya. Untuk dapat menggunakan bahasa secara wajar seseorang harus berkompeten dalam dua hal yaitu punya kom- petensi linguistik dan punya kompetensi komunikasi. Yang dimaksud kompetensi linguistik adalah pengetahuan yang berkaitan dengan masalah bahasa apakah itu yang berkaitan dengan: sistem pelafalan (fonem), leksikon, dan gramatika (morfologi dan sintaksis) dan yang dimaksud dengan kompetensi komunikasi adalah pengetahuan yang berkaitan dengan masalah penggunakan bahasa secara 
tepat, wajar, dan sesuai dengan situasi.

Dalam pandangan fungsional, saat seseorang mengujarkan sebuah kalimat, secara bersamaan dia melakukan tindakan. Pada dasarnya, kalimat tanya adalah kalimat yang diujarkan untuk mengetahui tentang sesuatu. Bagi masyarakat Indonesia kalimat tanya diujarkan tidak hanya untuk menanyakan sesuatu tetapi juga digunakam untuk menyatakan atau menindakkan berbagai hal seperti untuk menyatakan keramahtamahan, keheranan, simpati, marah, memohon sesuatu dan sebagainya.

Pertanyaan tidak pernah hadir secara mandiri. Dia hadir dalam sebauh peristiwa tutur. Jadi, untuk memahami penggunaan berbagai bentuk kalimat tanya bahasa Indonesia haruslah dilihat dalam kontek yang lebih luas yaitu dalam suatu peristiwa tutur. Artinya, penelusuran makna dan fungsi tuturan tanya haruslah dalam konteks. Kalimat yang berada dalam konteks itu biasa disebut dengan tuturan atau ujaran.

Istilah kalimat tanya timbul sebagai hasil pengkategorian kalimat berdasarkan respon lawan tutur sesaat setelah sebuah kalimat diujarkan. Berdasarkan respon lawan tutur itu, kalimat dibedakan atas kalimat berita, tanya dan perintah. Kalimat tanya pada dasarnya diujarkan dengan harapan lawan tutur merespon dengan tuturan jawaban. Saat seseorang menuturkan tuturan kalimat tanya secara bersamaan dia juga menyampaikan suatu tindak tutur. Tindak tutur yang tersimpan dalam kalimat tanya bahasa Indonesia bisa bermacam-macam.

Pertuturan atau yang disebut juga dengan tindak tutur merupakan bidang pragmatik yang cukup banyak diperhatikan ahli bahasa sekarang ini. Kajian tindak tutur ini lebih mengutamakan kajian makna sebuah ujaran. Teori ini memandang semantik di dalam konteks komunikasi yang lebih luas dan membentuk tindak tutur ketimbang kalimat sebagai unit dasar dari komunikasi manusia.
Berbeda dengan filusuf bahasa dan logika terdahulu atau yang segenerasi dengannya, yang cendrung melihat bahasa hanya berfungsi sebagai pendeskripsi hal yang ada dialam sekitar, seorang filusuf berkebangsaan Inggris, John L. Austin (1962) mengembangkan teori fungsi bahasa yang kemudian disebut dengan teori 'tindak tutur' atau speech act. Austin lebih melihat fungsi bahasa dalam kaitanya fungsi sosial dan interpersonal. Teori yang diajukan Austin ini lebih menampakkan dirinya sebagai teori tindakan atau theory of action. Hal itu dikarenakan teori ini berangkat dari pandangan yang meyakini bahwa ketika seseorang bertindak dengan sengaja, ia juga memiliki maksud tertentu ... by saying or in saying something we are doing something. Pandangan ini berseberangan dengan tokoh terdahulu dan sezamannya yang memandang bahwa mengatakan sesuatu berarti menyatakan sesuatu.

Istilah teori tindak tutur ini lebih gencar disosialisasikan oleh Searle (1969) melalui bukunya yang berjudul speech act. Sebagai pelanjut Austin, Searle dalam teori tindak tuturnya ini juga berangkat dari pandangan bahwa aktivitas berbahasa merupakan aktivitas menindakkan sesuatu. Dalam mengklasifikasi tindak ilokusi, Searle mengusulkan tiga kriteria utama, yaitu illocutionary point atau tujuan tindakilokusi, direction of fit atau arah persesuaian, dan sincerity condition atau syarat ketulusan. Searle (1969:10) mengatakan "What I propose to do is take illocutionary point, and its corrolaries, direction of fit and and expressed sincerity conditions, as the basis for construction a classification. Berdasarkan kriteria itu Searle mengklasifikasikan tindak ilokusi atas lima kelompok. Kelima kelompok itu adalah Representatives atau Assertives, Directives, Commissives, Expressives dan Declaration.

Uraian maksud dari kelima macam tindak ilokusioner itu adalah sebagai berikut. Pertama, tindak representatif, 
yakni tindak yang merepresentasikan sesuatu, misalnya pernyataan, deskripsi, penegasan. Kedua, tindak direktif, yakni tindak yang mengandung maksud menyuruh seseorang melakukan sesuatu; misalnya: perintah, permintaan, instruksi. Ketiga, tindak komisif, yakni tindak yang membuat penutur melakukan perbuatan di masa yang akan datang; misalnya :janji, tawaran, ancaman. Keempat, tindak ekspresif, yakni tindak yang mengungkapkan sikap penutur tantang sesuatu. Misalnya: ungkapan maaf, ungkapan terima kasih, ungkapan untuk menyambut sesorang. Kelima, tindak deklaratif yakni tindak yang menyebabkan suatu berhubungan dengan sesuatu yang sedang disebutkan; misalnya menyataka perang, akad nikah, pemecatan.

Agar berhasil dilaksanakan dengan baik, tindak ilokusi harus memenuhi beberapa syarat yang disebut dengan felicity conditions. Syarat-syarat itu berbeda untuk setiap jenis tindak ilokusi namun ada tiga syarat yang berlaku secara umum. Syarat umum itu adalah preparatory conditions, sincerity conditions, dan essential conditions. Preparatory conditions atau prasyarat mewajibkan orang yang melakukan tindakan untuk memiliki hak atau wewenang untuk melaksanakannya dan situasi ujarnyapun harus sesuai dengan tindak ilokusinya. Pelanggaran atas prasyarat ini akan menyebabkan tindak ilokusinya tidak berhasil atau 'misfire' (Austin 1962:16). Sincerity conditions atau syarat ketulusan mengharuskan orang yang melaksanakan tindakan untuk sungguh-sungguh dan tulus melakukannya, dalam arti tidak berbohong. Pelanggaran terhadap syarat kedua ini memang tidak mengakibatkan kegagalan tindak ilokusinya, melainkan orang tersebut dapat dituduh melakukan apa yang disebut Austin 'abuse'. Essential conditions atau syarat pokok mewajibkan orang yang melakukan tindakan untuk memiliki komitmen, keyakinan atau niat yang sungguh-sungguh untuk melaksanakan tindakan tersebut. Apa- bila seseorang melakukan suatu tindakan yang tidak sesuai dengan tindak ilokusi dalam ujarannya, maka ia dapat dianggap melanggar komitmen. Menurut Lyon (1977:734), komitmen dalam hal ini bukan berarti bahwa kita harus percaya terhadap apa yang kita katakan. "Comitment is independent of sincerity and truth; is a matter of appropriete behaviour".

Searle juga membedakan antara tindak tutur langsung dengan tindak tutur tidak langsung. Yang dimaksudnya dengan tindak tutur tidak langsung adalah ujaran yang tindak ilokusinya dilakukan melalui pelaksanaan tindak tutur lain yang literal. Sebaliknya, yang dimaksud dengan tindak tutur tidak langsung adalah tindak ilokusi literal yang memungkinkan disimpulkannya tindak ilokusi non literal yang dimaksudkan. Berkaitan dengan jenis tindak tutur langsung dan tidak langsung ini dalam bahasa Indonesia Wijana (1996: 29-33 ) juga telah menjelaskan. Di samping itu, Searle mengemukakan bahwa ada kaidah yang mengatur bentuk tingkah laku pertuturan, apakah itu kaidah etika atau kaidah ke-sopanan. Hipotesis ini dikemukan Searle berdasarkan keyakinan bahwa semantik suatu bahasa dapat dianggap sebagai serangkaian sistem kaidah yang konstitutif dan bahwa tindak ilokusioner adalah tindak yang dilakukan sesuai dengan kaidah yang konstitutif tersebut.

\section{METODE}

Dalam melaksanakan penelitian ini digunakan tiga macam metode penelitian, dan antara ketiga metode itu terkait dalam satu rangkaian, di mana setiap metode itu merupakan tahapan strategis penanganan masalah sehingga penelitian itu selesai. Ketiga metode itu adalah metode pengumpulan data, motode analisis data, dan metode penyajian hasil analisis data (Sudaryanto, 1988).

Pengumpulan data lisan di lapangan menggunakan metode simak dengan dasar teknik dengar atau "nguping". Dalam pengumpulan data itu juga di- 
gunakan teknik pancing, yaitu teknik yang melibatkan peneliti dalam proses komunikasi. Teknik pancing ini digunakan untuk mendapatkan dan menguji kesahihan data. Kegiatan pengumpulan data dianggap selesai setelah dilakukan klasifikai secara sederhana.

Pada tahap analisis digunakan analisis kontekstual. Metode yang digunakan adalah metode padan pragmatik. Metode padan pragmatik digunakan untuk mengurai komponen tutur yang terkandung dalam sebuah kalimat tanya sehingga dapat ditentukan jenis tindak tutur yang dinyatakan oleh sebuah tuturan tanya. Laporan hasil penelitian disajikan secara informal artinya dijelaskan secara verbal.

\section{HASIL DAN PEMBAHASAN}

Kalimat tanya adalah kalimat yang dituturkan dengan harapan lawan tutur merespon dengan memberi jawaban atas apa yang ditanyakan (Moeliono, dkk 1988). Selain untuk menanyakan tentang sesuatu, kalimat tanya juga berfungsi untuk menyatakan berbagai hal. Dari penelitian ditemukan bahwa kalimat tanya bahasa Indonesia dapat memasuki berbagai klas atau jenis tindak tutur. Sebuah kalimat tanya adakalanya dapat menyatakan lebih dari satu macam fungsi. Misalnya, selain menyatakan pelarangan, kalimat tanya itu juga menyatakan perintah dan di ujung semua itu adakalanya penutur bermaksud menyatakan kekecewaan atas apa yang dilakukan lawan tutur. Dengan melihat adanya keragaman fungsi tutur kalimat tanya itu, dapat dipahami bahwa bahasa selain berfungsi imformatif juga menjalankan fungsi ekspresif. Contoh:

(1) Jam berapa ini? atau Ini sudah jam berapa ini?

Kalimat tanya (1) ini berfungsi untuk menanyakan waktu apabila penutur tidak sedang melihat jam sebagai penunjuk waktu. Akan tetapi jika pertanyaan itu dilontarkan oleh seseorang yang mana dia sedang memegang jam, maka kalimat tanya itu diujarkan untuk fungsi yang lain. Kalimat tanya itu bila dituturkan dalam konteks yang berbeda akan mempunyai fungsi yang berbeda. Dengan kalimat tanya (1) itu setidakknya ada lima fungsi pertuturan yaitu untuk menyatakan peringatan, mengusir, menyuruh bersegera, menanyakan alasan keterlambatan, dan marah kepada seseorang karena sudah sangat terlambat datang. Kalimat tanya yang menanyakan jam itu berfungsi untuk mengingatkan biasanya diujarkan oleh seorang ibu yang ditujukan kepada anaknya yang masih tidur atau melakukana kegiatan yang lain yang mana pada waktu itu anak itu sudah harus melakukan kegiatan yang lainnya. Jika tuturan tanya seperti itu diujarkan oleh seorang suami kepada istrinya yang masih berdandan, itu berarti kalimat tanya dituturkan untuk fungsi menyuruh agar sang istri bersegera berdandan untuk dapat segera berangkat. Jika kalimat tanya itu dituturkan oleh seorang orang tua yang anaknya diapeli oleh pacarnya dimana pacar anaknya itu masih berada dirumah saat jam tamu sudah berakhir, maka kalimat tanya seperti itu dituturkan untuk menyatakan pengusiran atau menyuruh pulang pacar anaknya. Kalau ujaran tanya seperti itu dituturkan oleh seorang dosen atau guru kepada seorang mahasiswa yang terlambat masuk kelas, maka tuturan itu biasanya direspon dengan menyebut alasan keterlambatan dari mahasiswa itu. Dalam konteks tutur yang demikian itu tuturan tanya berfungsi untuk menanyakan alasan keterlambatan mahasiswa. Kalau tuturan yang sama ini diujarkan oleh seorang ibu kepada anaknya yang pulang sudah sangat larut malam, maka tuturan ini berfungsi menyatakan marah kepada anaknya karena sudah sangat terlambat pulang.

Begitu banyak dan bervariasinya isi dan fungsi tutur kalimat tanya dalam bahasa Indonesia. Berdasarkan klasifikasi Searle, kalimat tanya bahasa Indonesia dapat digunakan untuk menyatakan 
empat macam fungsi tindak ujar yaitu fungsi representatif, direktif, komisif dan ekspresif. Tidak ditemukan data kalimat tanya yang berfungsi deklaratif. Tuturan deklaratif berhubungan dengan sesuatu yang sedang disebutkan; misalnya menyatakan perang, akad nikah, pemecatan, dll. Tuturan deklaratif berisi ketetapan dan orang yang menuturkan harus punya otoritas untuk menyatakan ketetapan itu. Kalimat tanya yang pada dasarnya bersifat negosiatif tidak mungkin digunakan untuk menyatakan tindak deklaratif yang berisi ketetapan-ketetapan.

\section{Tindak Representatif}

Tindak tutur representatif adalah tindak yang merepresentasikan sesuatu; misalnya pernyataan, deskripsi, penegasan, dll. Kalimat tanya yang dituturkan untuk merepresentasikan sesuatu itu secara bersamaan dapat berfungsi fatis untuk menyapa, menyatakan simpati atau keprihatinan, menyumpahi, mencurigai, menuduh, menyangkal, melecehkan, dan memuji. Berikut ini adalah contohcontoh kalimat tanya bahasa Indonesia yang termasuk kategori tindak tutur representatif

(2) a. Berangkat Buk?

b. Sakit, ya?

c. Sakit, kan?

d. Boleh mengganggu sebentar Pak?

e. Makan, ya?

f. Siapa bilang kamu bodoh?

g. Anda fikir Anda siapa?

h. Kamu kok cantik sekali hari ini?

i. Dia kok bisa lulus?

Tuturan tanya (2a) dituturkan sesungguhnya bukan untuk meminta informasi tentang sesuatu, tetapi digunakan hanya untuk menyatakan keramahtamahan, yaitu untuk menyapa seseorang. Dengan fungsi yang demikian respon yang muncul dapat berupa jawaban yang menyatakan pengiaan atau penidakan. Kalau diamati jawaban yang kerap muncul dalam ben- tuk pengiaan. Hal itu dikarenakan hal ditanyakan adalah soal kebiasaan yang dapat telihat dari pakaian atau dari yang lainya.

Kalimat tanya $(2 b)$ ini diujarkan untuk menyatakan simpati dalam hal ini ikut merasakan kesusahan orang lain. Bila seorang melihat orang lain terutama anak-anak atau orang yang pantas disayangi mengalami sesuatu yang tidak menyenangkan maka petanya menyatakan keprihatinannya dengan menuturkan ujaran seperti $(2 b)$ di atas. Dengan intonasi tertentu, tuturan (2b) juga digunakan untuk mengajuk. Situasinya, misalnya seorang anak bermalas-malas untuk berangkat sekolah dengan tidak bangkit dari tempat tidur. Untuk memastikan alasan anak tersebut tidak bangkit, maka ibu itu biasanya bertanya dengan ujaran tanya (2b). Jenis partikel yang muncul diakhir kalimat tanya menyebabkan terjadinya perubahan fungsi tuturan. Hal itu dapat dilihat pada contoh (2c) yang berakhir dengan partikel kan. Tuturan tanya (2c) menyatakan "sumpahan". Ujaran ini biasanya dituturkan seseorang setelah. memberi peringatan pada anak dan anak itu tetap melanggar sehinga mengalami kesakitan, maka respon muncul dalam bentuk kalimat tanya (2c) .

Kalimat tanya seperti (2d) di atas biasanya diujarkan oleh seseorang dalam situasi tutur yang resmi, misalnya diperkantoran. Kalimat itu biasanya diujarkan oleh bawahan kepada atasan dengan tujuan untuk meminta izin utamanya izin berbicara untuk menyampaikan sesuatu. Kalimat tanya juga dapat berfungsi untuk menyatakan tuduhan. Hal itu diperlihatkan oleh contoh (2e). Menuduh adalah menunjuk dan mengatakan bahwa seseorang melakukan perbuatan melanggar hukum. Kalimat tanya (2e) biasanya dituturkan untuk menuduh orang yang tidak puasa di bulan Ramadan. Norma pada bulan Ramadan, orang Islam dilarang makan pada siang hari. 
Kata menyangkal dalam bahasa Indonesia berpadanan artinya dengan beberapa kata lainnya seperti mengingkari; tidak membenarkan; membantah; melawan; menentang; menyanggah. Ada beberapa bentuk kalimat tanya bahasa Indonesia yang difungsikan untuk menyatakan peyangkalan. Kalimat tanya (2f) adalah salah satu bentuknya. Isi dari kalimat tanya (2f) di atas sesungguhnya menyatakan hal yang kontradiksi dengan apa yang dinyatakan dalam kalimat tanya. Hal yang dinyatakan dalam kalimat tanya itu adalah Kamu tidak bodoh.

Kalimat tanya seperti (2g) di atas diujarkan oleh penutur kepada lawan tutur dimana penutur menganggap lawan tutur telah bertindak atau melakukan sesuatu melebihi wewenangnya atau penutur menganggap lawan tutur tidak pantas melakukan suatu tindakan. Selain untuk menyatakan pelecehan, kalimat tanya seperti (2g) ini juga diujarkan untuk menyatakan protes terhadap lawan tutur yang dianggap telah melakukan sesuatu melebihi kapasitasnya.

Memuji adalah menuturkan kalimat untuk menyatakan rasa pengakuan dan penghargaan yang tulus akan kebaikan atau keunggulan sesuatu. Kalimat tanya (2h) adalah contoh kalimat tanya yang difungsikan untuk menyatakan pujian. Kebalikan dari memuji adalah mencela yang artinya mengatakan bahwa sesuatu ada buruknya atau kurangnya. Kata mencela bersinonim dengan kata mengkritik, mengecamdan dan menghina. Kalimat tanya yang dibentuk dari proposisis yang prediketnya terdiri dari kata sifat yang menyatakakan keadaan yang positif itu dituturkan untuk memuji lawan tutur. Kalau kata-kata yang menjadi prediketnya berupa kata sifat yang bernuansa negatif, maka ujaran tanya berfungsi untuk menyatakan celaan. Contoh: Kok kamu kotor sekali?

Kalimat tanya (2i) dituturkan untuk menyatakan kecurigaan. Hal itu disebabkan misalnya karena penutur melihat adanya kontradiksi. Dalam anggapan penutur seseorang atau orang ketiga itu tidak bisa lulus karena menurut anggapan penanya orang itu tidak pantas lulus karena selama ini diketahuinya orang ketiga itu malas atau bodoh

\section{Tindak Direktif}

Tindak direktif adalah tindak yang mengandung maksud menyuruh seseorang melakukan sesuatu; misalnya: mengajak, perintah, permintaan, instruksi, dll. Kalimat tanya bahasa Indonesia yang menyatakan tindak direktif dituturkan untuk maksud menawarkan, menyarankan, mengingatkan, meminta, menyuruh, melarang, menyuruh paksa. Contoh contoh kalimat tanya yang dituturkan untuk menyatakan tindak direktif itu di antaranya adalah:

(3) a. Mau masuk?

b. Kenapa kuenya tidak dimakan?

c. Sudahkah Anda membayar pajak?

d. Kenapa kita tidak berangkat saja sekarang?

e. Apa (kah)) Anda punya korek?

f. Bisa Anda bawa buku ini?

g. Kalian bisa diam ngak?

h. Siapa lagi yang buang sampah sembarangan?

i. Boleh ya?

j. Mau keluar lagi?

Menawarkan artinya mengunjukkan sesuatu kepada (dengan maksud supaya dibeli, dikontrak, diambil, dipakai. Kalimat tanya (3a) dituturkan untuk mengajak lawan tutur masuk ke satu ruangan atau satu tempat. Hampir sama dengan fungsi tutur, kalimat tanya (3a). kalimat tanya (3b) juga berfungsi untuk menyatakan penawaran. Kalau kata mengajak berarti menyuruh lawan tutur melakukan sesuatu yang tidak menyebabkan kerugian pada penutur, sementara kata menawarkan membawa makna yang menyebabkan kerugian pada penutur. Kalimat tanya (3b) biasanya dituturkan dalam konteks 
dimana kue sudah dihidangkan belum dimakan. Tuturan tanya digunakan untuk menawarkan ulang. Ada norma bahwa kue yang sudah diletakkan kalau pun sudah dipersilahkan satu kali, tamu belum mau memakan. Nah untuk memastikan bahwa yang terhidang betul-betul boleh dimakan maka penutur kembali mempersilahkan dengan mengujarkan kalimat tanya seperti pada contoh (3b).

Salah satu arti dari kata mengingatkan adalah memberi nasehat atau teguran kepada seseorang supaya ingat akan kewajiban. Kalimat tanya (3c) di atas adalah contoh kalimat tanya yang dituturkan dengan maksud mengingatkan seseorang akan kewajibannya. Kalimat tanya seperti pada kelompok (3c) di atas biasanya ditemukan ditempat umum yang bertujuan untuk mengingatkan pembaca melakukan hal yang dinyatakan dalam kalimat tanya. Penulis atau penutur di sini bersifat anonim yang bisa saja mewakili kelompok orang atau lembaga tertentu. Kelompok orang atau lembaga itu bertujuan mengingatkan pembaca untuk melakukan sesuatu karena adanya keharusan pada pembaca untuk melakukan atau berlaku seperti yang dinyatakan dalam kalimat tanya.

Kalimat tanya dapat difungsikan untuk menyatakan saran. Menyarankan atau memberi saran adalah menuturkan kalimat dengan tujuan agar lawan tutur mempertimbangkan usul atau anjuran yang dikemukakan seseorang. Kalimat tanya (3d) adalah contoh kalimat tanya yang dituturkan untuk menyarankan sesuatu kepada lawan tutur dalam hal ini agar berangkat sekarang.

Kalimat tanya dapat difungsikan untuk menyatakan permintaan. Arti kata meminta dalam bahasa Indonesia cukup banyak, seperti: berharap-harap agar diberi atau mendapat sesuatu, mempersilakan, meminang, dan memerlukan. Kalimat tanya yang difungsikan untuk meminta disini seperti (3e) berarti berharap agar lawan tutur memberikan sesuatu yang dibutuhkan penanya.

Kalimat tanya (3f) diujarkan sesungguhnya bukan mempertanyakan kemampuan atau kesediaan lawan tutur untuk melakukan sesuatu yang dinyatakan dalam kalimat tanya. Penanya sudah yakin petanya mampu melakukan hal yang dinyatakan dalam kalimat tanya itu. Kalimat tanya (3f) sesungguhnya difungsikan untuk menyatakan suruhan.

Masih dalam fungsi direktif, kalimat tanya (3g) dituturkan untuk menyatakan perintah. Memerintah artinya sama dengan menyuruh yaitu: memberi perintah atau menyuruh lawan tutur melakukan sesuatu. Dalam bahasa Indonesia, terutama dalam bahasa lisan ada beberapa bentuk kalimat tanya yang difungsikan untuk menyatakan perintah. Kalimat tanya (3g) merupakan salah satu bentuk kalimat tanya yang difungsikan untuk memerintah itu dalam hal ini perintah untuk diam.

Kalimat tanya seperti (3h) di atas diujarkan untuk menyatakan kekesalan karena lawan tutur melakukan sesuatu yang tidak seharusnya. Sesungguhnya kalimat tanya ini menyatakan tindak tutur direktif yang berisi larangan pada lawan tutur untuk tidak melakukan sesuatu dan sekaligus berisi perintah untuk melakukan hal yang lain. Isi kalimat tanya itu sesungguhnya adalah: Sampah jangan dibuang sembarangan, tetapi Buanglah sampah pada tempatnya!.

Memaksa berarti memperlakukan, menyuruh, meminta seseorang dengan kekerasan (mendesak, menekan) untuk melakukan sesuatu. Kalimat tanya yang difungsikan untuk memaksa adalah kalimat tanya yang dituturkan agar lawan tutur melakukan apa yang diharapkan penutur. Contoh (3i) adalah kalimat tanya yang dituturkan untuk menyatakan paksaan kepada lawan tutur. Kalimat tanya seperti (3i) berfungsi untuk menyatakan pemaksaan karena dituturkan oleh seseorang yang status sosialnya lebih 
tinggi kepada orang yang status sosialnya lebih rendah, seperti pemimpin kepada bawahannya. Lawan tutur tidak punya kebebasan untuk menentukan apakah dia akan melakukan atau menolak apa yang diperintahkan penutur.

Melarang adalah kata yang maknanya beroposisi dengan kata-kata yang menyatakan tindak direktif yang telah dibahas pada bagian terdahulu, seperti menyuruh, menyaranlan, meminta, dsb. Melarang artinya memerintah untuk tidak melakukan sesuatu atau tidak memperbolehkan melakukan sesuatu. Kalimat tanya (3j) adalah contoh kalimat tanya yang berisi larangan. Kalimat-kalimat tanya kelompok (3j) ini diujarkan untuk menyatakan ketidaksetujuan penutur atas apa yang akan dilakukan lawan tutur seperti apa yang dinyatakan dalam kalimat tanya. Dalam kalimat tanya (3j), penutur tidak menginginkan lawan tutur pergi lagi. Oleh karena itulah ujaran itu dapat difungsikan untuk melarang karena penanya berharap lawan tutur tidak melakukan aktifitas seperti yang dinyatakan dalam kalimat tanya. Kalimat ini biasa diujarkan dengan suasana hati yang kesal atau marah.

\section{Tindak Komisif}

Tindak komisif adalah tindak yang membuat penutur melakukan perbuatan di masa yang akan datang; misalnya: janji, tawaran, ancaman, dll. Tindak komisif yang dapat dinyatakan dengan kalimat tanya di antaranya adalah: mengajak, menawarkan bantuan, mengajuk, dan menantang. Berikut ini adalah contoh-contoh kalimat tanya untuk masing-masing fungsi tutur itu.

(4) a. Bagaimana kalau kita menonton nanti malam?

b. Ada yang bias saya bantu?

c. Sepeda ini masih bisa dipakai ngak?

d. Kalau saya tidak mau bayar kamu mau apa?
Mengajak adalah meminta, menyilakan, menyuruh seseorang untuk ikut serta melakukan suatu akaktifitas yang dilakukan oleh penanya. Kalimat tanya (4a) ini dapat masuk kelompok komisif karena penutur mengajak lawan tuturnya melakukan kegiatan secara bersama-sama dengan penutur. Kalimat tanya (4b) di atas menyatakan penawaran. Kalimat tanya seperti (4b) di atas biasanya diujrakan oleh seseorang kepada lawan tuturnya untuk menawarkan bantuan.

Kata mengajuk bersal dari kata ajuk yang artinya memeriksa atau hendak mengetahui (isi hati, perasaan atau pikiran orang). Kalimat tanya yang difungsikan untuk mengajuk isinya mencari tahu tentang sesuatu apakah itu isi hati, perasaan, pikiran seseorang atau keadaan sesuatu. Kalimat tanya (4c) berfungsi mencari tahu apakah lawan tutur mengizinkan penutur melakukan hal yang ingin dilakukannya, dalam hal ini memakai sepeda milik lawan tutur.

Kalimat tanya yang berfungsi untuk menyatakan tantangan adalah kalimat tanya yang dituturkan untuk menyatakan tantangan kepada lawan tutur yang wujudnya berkelahi bertanding, berperang atau menghadapi masalah. Kalimat tanya seperti (4d) di atas sesungguhnya berisi pernyataan bahwa penutur tidak mau membayar sesuatu yang seharusnya dibayar oleh penutur.

\section{Tindak Ekspresif}

Tindak ekspresif adalah- tindak yang mengungkapkan sikap penutur tantang sesuatu; misalnya: ungkapan maaf, ungkapan terima kasih, ungkapan untuk menyambut sesorang, dll. Kalimat tanya bahasa Indonesia dapat digunakan untuk menyatakan sikap penutur yang mengekspresikan berbagai situasi psikologis penutur seperti: keheranan (kaget), kesangsian, kekhawatir, kekecewaan, penyesalan, kekesalan, protes, dan kemarahan. Pada dasarnya semua kata ini berada dalam satu domain kosa kata yang menyatakan 
sikap negatif seseorang tentang sesuatu. Semua kata itu berhubungan dan satu di antaranya bergradasi secara kuantitas maupun secara kualitasnya. Berikut ini adalah contoh-contoh kalimat tanya bahasa Indonesia yang yang dituturkan untuk menyatakan fungsi emotif.

(5) a. Siapa sangka dia yang membunuh istrinya?

b. Begitu kah? Atau Begitu ya?

c. Banyak nyamuk, ya?

d. Kok kalian sampai hati membiarkan dia pulang sendiri?

e. Buku ini kenapa ditaruh di sini?

f. Siapa lagi yang buang sampah sembarangan?

g. Masak dia menyuruh saya mencuci piring sebanyak itu?

h. Mengapa kita yang harus membayar utangnya?

i. Ngak baca, ya?

j. Berapa kali saya harus mengatakan, datang harus tepat waktu?

Kalimat tanya (5a) biasanya dituturkan untuk menyatakan keheranan. Kata heran berarti merasa ganjil ketika melihat atau mendengar sesuatu. Tuturan tanya seperti (5a) heran atas perbuatan yang dilakukan seseorang. Penutur berkeyakinan bahwa seseorang dalam hal ini orang ketiga tidak mungkin akan membunuh istrinya karena dalam pandangannya orang itu baik dan hubungan orang itu dengan istrinya baik-baik saja.

Kata menyangsikan berasal dari kata sangsi yang artinya bimbang; ragu-ragu. Menyangsikan berarti meragukan, menaruh syak akan. Kalimat tanya seperti (5b) di atas dituturkan untuk menyatakan kesangsian atas kebenaran penjelasan atau kebenaran berita yang disampaikan seseorang. Hampir sama dengan kata sangsi, dalam bahasa Indonesia ada kata khawatir yang artinya takut, gelisah, cemas terhadap suatu hal yang belum diketahui dengan pasti. Kalimat tanya (5c) diujarkan untuk menyatakan kekhawatiran penutur atas keadaan, peristiwa yang dianggap kurang menyenangkan yang dirasakan atau dialami oleh lawan tutur. Kalimat tanya seperti (5c) itu diujarkan saat melihat lawan tutur tidak nyaman karena digigit nyamuk. Secara bersamaan kalimat tanya itu dituturkan untuk menyatakan rasa simpati penutur atas ketidaknyamanan yangdialami lawan tutur.

Salah satu kosa kata yang menyatakan suasana hati seseorang adalah kata kecewa. Kecewa adalah suasana hati yang berada dalam keadaan tidak senang; tidak puas karena tidak terkabul keinginannya, harapannya dsb. Tuturan (5d) adalah salah satu contoh kalimat tanya yang dituturkan untuk mengekspresikan suasana hati atau perasaan yang kecewa. Kalimat tanya ini diujarkan untuk menyatakan penyesalan atau kekecewaan penutur atas tindakan atau sikap lawan tutur atau pihak ketiga. Menurut penutur, lawan tutur atau orang ketiga tidaklah pantas melakuakan sesuatu atau bersikap seperti yang dinyatakan dalam kalimat tanya.

Kalimat tanya (5e) diujarkan untuk menyatakan kekesalam karena lawan tutur melakukan hal yang tidak seharusnya. Hampir sama dengan kalimat tanya (5e). kalimat tanya (5f) juga dituturkan untuk menyatakan kekesalan. Sesungguhnya kalimat tanya (5f) ini menyatakan tindak tutur direktif yaitunya menyatakan larangan pada lawan tutur untuk melakukan sesuatu seperti yang dinyatakan dalam kalimat tanya dan pada waktu yang sama penutur menyarankan lawan tutur melakukan hal lain yang dianggap lebih tepat atau lebih pantas.

Memprotes berarti menyatakan tidak setuju atau menyangkal. Kalimat tanya yang dituturkan untuk menyatakan protes ada beberapa macam. Dua diantaranya adalah kalimat tanya (5g) dan (5h). Kalimat tanya (5g) dituturkan untuk menyatakan protes karena disuruh melakukan sesuatu yang tidak sepantasnya dan kalimat tanya (5h) menyatakan protes karena dituntut bertanggung jawab atas sesuatu 
hal. Menurut penutur dia tidaklah orang seharusnya melakukan hal yang dinyatakan dalam kalimat tanya yang dalam hal ini membayar hutang.

Marah adalah suasana jiwa yang berada dalam keadaan sangat tidak senang karena dihina, diperlakukan tidak sepantasnya dsb. Kalimat tanya yang dituturkan untuk menyatakan marah di antaranya adalah seperti pada contoh (5i) dan (5j). Kalimat tanya (5i) misalnya, diujarkan kepada seseorang yang melakukan kesalahan karena tidak membaca peraturan ditempat umun, misalnya seseorang memarkir mobil atau sepeda motor yang ditempat itu ada tulisan Dilarang parkir di lokasi ini. Seseorang tetap memarkir ditempat terlarang itu. Satpan atau orang lain akan menegur orang yang memarkir kendaraan ditempat yang salah itu dengan menggunakan kalimat tanya seperti pada (5i) di atas. Kalimat tanya (5j) ini digunakan untuk menyatakan peringatan kepada seseorang untuk mengkentikan pekerjaan atau kegiatan yang sudah dilarang berkali kali. Kalimat seperti ini biasanya dituturkan oleh orang dewasa kepada anak kecil. Misalnya, seorang guru yang marah kepada muridnya yang selalu datang terlambat.

\section{SIMPULAN}

Selain untuk bertanya, kalimat tanya dalam bahasa Indonesia dapat difungsikan untuk menyatakan berbagai tindak tutur. Tindak tutur yang dapat dinyatakan dengan kalimat tanya bahasa Indonesia adalah representatif, direktif, komisif, dan ekspresif. Beberapa kalimat tanya adakalanya dapat dimasukkan ke dalam lebih dari satu jenis tindak tutur. Pada saat yang sama sebuah kalimat tanya dapat saja masuk kedalam kelas tindak tutur representatif dan ekspresif (menolak dan memprotes). Kalimat tanya yang berfungsi untuk menyatakan penawaran (direktif) secara simultan (inheren) juga menyatakan keramah tamahan dalam rangka berbasa basi yang dalam penge- lompokan Searle masuk ke dalam kelas ekspresif.

Penggunaan kalimat tanya untuk menyatakan berbagai macam tindak tutur itu menyebabkan tuturan menjadi lebih ekspresif atau emotif. Penggunaan bahasa yang demikian memperlihatkan kepada kita bahwa bahasa tidak hanya berfungsi komunikatif, tetapi juga berfungsi ekspresif. Dari data yang dianalisis terlihat bahwa banyak bentuk kalimat tanya yang berfungsi untuk menyatakan emosi negatif (kesangsian, kekhawatir, kekecewaan, penyesalan, kekesalan, protes, dan kemarahan) dan sedikit yang berfungsi untuk mengungkapkan emosi positif. (hormat, sayang, gembira dsb). Hal itu mungkin disebabkan emosi positif dapat diungkapkan secara nonverbal seperti dengan belaian, senyum, tawa, dan sentuhan.

Kalimat tanya digunakan dalam rangka bertutur tidak langsung (indirect speech) untuk menjaga kesopanan (mengurangi kekerasan) dan adakalanya sebaliknya yaitu menyatakan dengan tegas, kasar dan bahkan ada yang dianggap kurang ajar. Kalimat tanya yang menyatakan berbagai macam tindak ilokusi itu bentuk dasarnya sama dengan kalimat tanya yang betulbetul digunakan untuk bertanya. Dengan penambahan partikel tertentu atau diujarkan dengan intonasi tertentu dan tekanan tertentu maka kalimat tanya itu menjadi berfungsi ganda yaitu menjalankan fungsi komunikatif dan ekspresif. Pemerolehan kompetensi untuk dapat menggunakan kalimat tanya secara wajar terjadi secara alamiah karena dibiasakan. Anak-anak yang berumur di atas dua belas tahun biasanya dapat menuturkan dan memahami berbagai bentuk kalimat tanya untuk berbagai fungsi tutur itu. Hal itu terjadi karena adanya pembiasaan penggunaan bahasa dalam konteks.

\section{UCAPAN TERIMA KASIH}

Artikel ini diangkat dari sebagian disertasi yang penelitiannya dilakukan pada 
tahun 2010. Penelitian ini dilakukan dalam rangka melengkapi syarat memperoleh gelar doktor bidang Linguistik di Universitas Gajah Mada Yogyakarta. Oleh karena itu, terima kasih disampaikan kepada Prof. Dr. I Dewa PutuWijana, S.U., M.A dan Prof. Dr. Soepomo Poedjosoedarmo selaku promotor dan ko-promotor.

\section{DAFTAR PUSTAKA}

Austin, J.L. 1962. How to Do Things withWords. New York: Oxford University Press.

Lyon, John. 1974. Introduction to Theoritical Linguistics. Cambridge: Cambridge University Press.
Meoliono, Anton M dan Soenjono Dardjowidjoyo (ed) 1988. Tata Bahasa Baku Bahasa Indonesia. Jakarta: Balai Pustaka.

Searle, J. 1969. Speech Act An Essay in the Philosophy of Language. Cambridge: Cambridge University Press

Sudaryanto. 1988. Metode Linguistik. Yogyakarta: Gadjah Mada University Prees.

Wijana, I Dewa Putu. 1996. Dasar-Dasar Pragmatik. Yogyakarta: Penerbit Andi. 